\title{
Assessment of the Serum Level of Interleukin-6 and Interleukin-10 in Newly Diagnosed Acute Myeloid Leukemia Patients and the Response to Induction Chemotherapy
}

\author{
ZAINAB A. ABD EL-HAFEZ, M.D.*; MADLEEN A. ABDOU, M.D.*; TAREQ S. AHMED, M.D.** and \\ MAI M. SALAH EL-DIN, M.Sc.*
}

The Departments of Clinical Pathology* and Clinical Oncology \& Nuclear Medicine**, Faculty of Medicine, Assiut University, Egypt

\begin{abstract}
Background: Acute leukemia is the most common hematological malignancy in adults, characterized by distorted proliferation of immature bone marrow-derived cells (BM blasts) that may also involve peripheral blood or solid organs. Blood cells and their marrow based progenitors are exquisitely responsive to their environment, and cytokines are an essential part of it. The overexpression of cytokines in leukemia patients declines in complete remission suggesting that these events are dependent on AML activity, possibly due to autonomous blast cytokine secretion.
\end{abstract}

Methods: Using ELISA kit, serum levels of IL-6, IL-10 were estimated before and after induction chemotherapy in 30 patients with AML from February 2015 to May 2016 from Clinical Oncology Department, Hematological Diseases Unit in Internal Medicine Department, Assiut University Hospital and Medical Oncology Department, South Egypt Cancer Institute and 20 age and sex matched healthy controls were also enrolled.

Results: IL-6 and IL-10 levels were significantly higher in newly diagnosed AML patients than in control group and their levels decreased when patients responded to induction chemotherapy (the blast cell count in their BM fall to >5\%).

Conclusion: Our study demonstrated the decrease in the serum level of two markers (IL-6 and IL-10) in AML patients after induction chemotherapy, suggesting that assessment of their levels may be used as a prognostic markers and beneficial in the evaluation of the therapy making them highly applicable to routine clinical laboratories.

Key Words: AML - Induction chemotherapy - ELISA - IL-6 $-I L-10$.

\section{Introduction}

ACUTE Myeloid Leukemia (AML) represents a group of hemopoetic stem cell disorders in which both failure to differentiate and proliferation in the

Correspondence to: Dr. Mai M. Salah El-Din,

E-Mail: mai galaxyy@yahoo.com stem cell compartment results in accumulation of non-functional myeloid cells termed myeloblasts and loss of normal hematopoietic function frequently resulting in fatal complications [1].

The etiology of AML is heterogeneous and complex, but it is widely accepted that both environmental and genetic factors play significant roles in the development of the disease. Immune system disorders have increased the understanding of leukemogenesis [2].

Little is known about the pathogenic events leading to initiation and progression of this disease, elevated regulatory $\mathrm{T}$ (Treg) cells in a variety of hematological malignancies including AML have been reported [3]. Patients with a lower Treg cell frequency at diagnosis have a better response to induction chemotherapy and a favorable diagnosis [4].

Considerable efforts have been spent in identifying prognostic markers that might predict clinical outcomes in AML patients and several characteristics including older age, cytogenetics and performance status are commonly used as predictors of survival. Prognosis in AML patients has been related to the frequently observed defective function of their immune system that hampers the development of effective response against leukemic blasts $[5,6]$.

Normally, Cytokines are secreted by different types of cells in response to a variety of stimuli such as tissue damage or infection and regulate the immune response and other biologic process.

In AML patients, cytokines can be produced by both leukemic blasts and cells of the immune 
system and the role of cytokines in the pathogenesis of acute leukemia has not been fully clarified [7] Thus, aberrant cytokine signaling is a feature of leukemia that may contribute to proliferation, blast survival, resistance to chemotherapy and patients" prognosis [8].

Interleukin-6 (IL-6) is a cytokine with pleiotropic inflammatory effects, has demonstrated different effects on the growth of leukemic blasts [4]. It may also exert anti-inflammatory biological activity by enhancing plasma interleukin-1 receptor antagonist (IL-1ra), interleukin-10 (IL-10) and cortisol in humans [9].

IL-10 is the most important anti-inflammatory cytokine found within the human immune response. It is a potent inhibitor of Th 1 cytokines, including both IL- 2 and IFN- $\gamma$. This activity accounts for its initial designation as cytokine synthesis inhibition factor [10]. In addition to its activity as a Th2 lymphocyte cytokine, IL-10 is also a potent deactivator of monocyte/macrophage proinflammatory cytokine synthesis [11]. The function of it has been detected in the leukemic cells of most ALL and AML cases and it suppresses the immune reactions, suggesting that IL-10 could be associated with escape of leukemia cells from immune surveillance [12] .

Interactions between pro-inflammatory and anti-inflammatory cytokines regulate cytokine response. Thus, tumour necrotic factor-alpha (TNF$\alpha)$ and IL- $1 \beta$ can stimulate their own and each other's production and also IL-6 secretion [13].

On the other hand, IL- 6 and TNF- $\alpha$ may induce IL-10 secretion with potential to inhibit IL-6, TNF$\alpha$ and IL-1 $\beta$ production. Changes in one of these cytokines lead to compensatory mechanisms that alter the cytokine network [14].

Aim of the work:

- To assess the serum levels of IL-6, IL-10 in newly diagnosed acute myeloid leukemia patients and after induction chemotherapy.

- To determine the relationship of the levels of these cytokines and the laboratory finding especially the bone marrow blast cells.

\section{Material and Methods}

This is a prospective case control study. It was carried out on patients from Clinical Oncology Department, Hematological Diseases Unit in Internal Medicine Department, Assiut University Hospital and Medical Oncology Department, South
Egypt Cancer Institute. This study included 30 patients with AML diagnosed by WHO classification and sub-classified (M1-M7) by FAB classification from February 2015 to May 2016. Age of the patients ranged from 20-68 years. Regarding gender, 12 cases were males and 18 were females as well as 20 age and sex matched healthy controls were also enrolled. The study was approved by the Ethical Committee of Faculty of Medicine, Assiut University. Consents were obtained from the patients before enrollment in this study.

The studied groups:

- First group: Included 30 newly diagnosed patients (ND) i.e. Before induction.

- Second group: Included the same 30 patients after ten days of induction chemotherapy with cytarabine (ara-C) and anthracycline (most often daunorubicin) (after induction).

- Third group: Included 20 apparently healthy individuals as control group.

Exclusion criteria:

- No medically unstable conditions (e.g., unstable diabetes, uncontrolled arterial hypertension, infection or ischemic heart disease).

- Not pregnant or nursing.

- No other previous or current malignant disease likely to interfere with protocol treatment or comparisons.

- No prior chemotherapy or radiotherapy.

Blood samples:

- Venous blood $(5 \mathrm{ml})$ was collected from patients prior and after induction of chemotherapy, also from control group.

- $2 \mathrm{ml}$ of venous blood was withdrawn into $\mathrm{K} 3$ EDTA tube for CBC.

\section{Method:}

For each patient, the following laboratory processes were done:

- Complete Blood Count (CBC) was done using CELL DYN (1700).

- Bone Marrow Aspiration (BMA) according to Dacie and Lewis Practical Hematology.

- Flow cytometry for immunophenotyping that was needed for the diagnosis of all cases by using FACS (fluorescence activated cell sorting) Caliber multicolor flow cytometry (BECTON DIKINSON, USA).

- Cytochemical tests. 
- Interleukin-6 ELISA assay by using:

Wuhan ELAab Science Co for Human interleukin-6 ELISA kit, Catalog No.: E00079h from China according to manufacturer instructions.

- Interleukin-10 ELISA assay by using:

Wuhan ELAab Science Co for Human interleukin-10 ELISA kit, Catalog No.: E00056h from China according to manufacturer instructions.

\section{Statistical analysis:}

Data collected and analyzed by computer program SPSS" Ver. 20" Chicago. USA. Data expressed as mean, Standard deviation, number and percentage. ANOVA test and Chi. Square were used to determine significance for categorical variable.

\section{Results}

This study included 30 newly diagnosed AML patients with age ranged from 20-68 years (Mean $\pm \mathrm{SD}, 40.76 \pm 16.75)$. According to sex, 12 cases were males $(40.0 \%)$ and 18 were females $(60.0 \%)$. Twenty healthy individuals were examined as control group with age ranged from 22-62 years (Mean $\pm \mathrm{SD}, 32.55 \pm 10.74$ ), 9 cases were male $(45.0 \%)$ and 11 were female $(55.0 \%)$.

Tables (1,2): Showed differences in peripheral heamogram elements between the patients and control group before and after induction chemotherapy. With significant difference $(p=0.00)$ between the two groups regarding $\mathrm{WBCs}, \mathrm{Hb}$ and platelets, where they were lower in the patients than control group except WBCs which was higher in the newly diagnosed patients (ND/before induction) than control group.

Table (3): Showed blast cells count in bone marrow before and after induction in the study group. With highly significant reduction in blast cells count after induction (mean \pm SD, 24.69 \pm 10.87 ; range, $1-78 \%$ ) than before induction (mean $\pm \mathrm{SD}, 58.10 \pm 23.10$; range, $20-93 \%)(p=0.000)$.

Table (4) and Fig. (1): Showed differences in IL-6 and IL-10 mean values of serum levels in newly diagnosed patients and control groups. With significantly higher values of IL-6 in the study group (mean $\pm \mathrm{SD}, 42.46 \pm 28.10$; range, 21.3-140.6 $\mathrm{pg} / \mathrm{ml}$ ) than the control group (mean $\pm \mathrm{SD}, 1.53 \pm$ 1.42 ; range $0.0-4.5 \mathrm{pg} / \mathrm{ml})(p=0.000 *)$ and IL-10 was higher in the study group (mean $\pm \mathrm{SD}, 177.68$ \pm 103.46; range, $26-432 \mathrm{pg} / \mathrm{ml}$ ) than the control group (mean $\pm \mathrm{SD}, 19.24 \pm 15.41$; range, 4.1-58.2 $\mathrm{pg} / \mathrm{ml})(p=0.000 *)$.
Table (5) and Fig. (2): Showed differences in IL-6 and IL-10 mean values of serum levels in in patients after induction and control groups. With significantly higher values of IL-6 in the study group (mean $\pm \mathrm{SD}, 37.02 \pm 26.36$; range, 10.7-125.3 $\mathrm{pg} / \mathrm{ml}$ ) than the control group (mean $\pm \mathrm{SD}, 1.53 \pm$ 1.42 ; range $0.0-4.5 \mathrm{pg} / \mathrm{ml})(p=0.000 *)$ and $\mathrm{IL}-10$ was higher in the study group (mean $\pm \mathrm{SD}, 135.60$ \pm 87.62 ; range, $16.0-270.5 \mathrm{pg} / \mathrm{ml}$ ) than the control group (mean $\pm \mathrm{SD}, 19.24 \pm 15.41$; range, 4.1-58.2 $\mathrm{pg} / \mathrm{ml})(p=0.000 *)$.

Table (6) and Fig. (3): Showed differences in IL-6 and IL-10 mean values of serum levels in in newly diagnosed patients and after induction. There was significant lower difference in serum level of IL-6 after induction chemotherapy (mean \pm SD, $37.02 \pm 26.36$; range, $10.7-125.3 \mathrm{pg} / \mathrm{ml}$ ) than before induction (ND) (mean $\pm \mathrm{SD}, 42.46 \pm 28.10$; range, $21.3-140.6 \mathrm{pg} / \mathrm{ml})(p=0.001)$ and also IL-10 was lower in after induction (mean $\pm \mathrm{SD}, 135.60 \pm$ 87.62 ; range, $16.0-270.5 \mathrm{pg} / \mathrm{ml}$ ) than before induction (mean $\pm \mathrm{SD}, 177.68 \pm 103.46$; range, $26-432$ $\mathrm{pg} / \mathrm{ml})(p=0.006)$.

Table (7) and Fig. (4): Showed correlations between serum levels of IL-6 and IL-10 concentrations and some of the laboratory parameters [age, White Blood Cells (WBCs), Hemoglobin level $(\mathrm{Hb})$, Platelets count (PLT), peripheral blast cells (P. blast) and bone marrow blast (B.M blast)] were analyzed in AML patients after induction chemotherapy. There were significant positive correlations between IL- 6 and BM. blasts ( $r=0.745$, $p=0.000 *$ ). There were no correlations between any of the other laboratory parameters and the cytokines concentrations.

Table (1): Profile of peripheral hemogram elements in newly diagnosed patients (before induction) and control groups.

\begin{tabular}{llll}
\hline Item & $\begin{array}{c}\text { Study } \\
\text { group } \\
\text { "n=30" }\end{array}$ & $\begin{array}{c}\text { Control } \\
\text { group } \\
\text { "n=20” }\end{array}$ & $\begin{array}{c}p- \\
\text { value* }\end{array}$ \\
\hline I- HB (g/dl) & $7.07 \pm 1.88$ & $12.80 \pm 0.955$ & $p=0.000^{* * *}$ \\
& $(3.6-11.7)$ & $(12.0-15.0)$ & \\
& & & \\
II- Platelets & $54.66 \pm 11.84$ & $256.60 \pm 54.29$ & $p=0.000^{* * *}$ \\
$(\mathrm{X} \mathrm{10} / \mathrm{L})$ & $(10.0-204.0)$ & $(150.0-340.0)$ & \\
VIII- WBCs & $22.90 \pm 4.80$ & $7.64 \pm 1.91$ & $p=0.002^{* *}$ \\
$\quad(\mathrm{X} \mathrm{10} / \mathrm{L})$ & $(1.1-103.0)$ & $(4.0-11.3)$ & \\
IV- P. Blast $(\%)$ & $40.89 \pm 29.50$ & - & - \\
& $(2.0-91.0)$ & & \\
\hline
\end{tabular}


Table (2): Profile of peripheral hemogram elements in patients after induction and control groups.

\begin{tabular}{|c|c|c|c|}
\hline Item & $\begin{array}{l}\text { Study } \\
\text { group } \\
\text { "n=30" }\end{array}$ & $\begin{array}{l}\text { Control } \\
\text { group } \\
\text { "n=20" }\end{array}$ & $\begin{array}{c}p- \\
\text { value* }\end{array}$ \\
\hline I- HB (g/dl) & $\begin{array}{l}8.26 \pm 1.39 \\
(6.0-11.90)\end{array}$ & $\begin{array}{l}12.80 \pm 0.955 \\
(12.0-15.0)\end{array}$ & $p=0.000 * * *$ \\
\hline $\begin{array}{l}\text { II- Platelets } \\
\left.\text { (X } 10^{9} / \mathrm{L}\right)\end{array}$ & $\begin{array}{l}88.74 \pm 39.87 \\
(7.0-355.0)\end{array}$ & $\begin{array}{l}256.60 \pm 54.29 \\
(150.0-340.0)\end{array}$ & $p=0.000 * * *$ \\
\hline $\begin{array}{l}\text { VIII- WBCs } \\
\left(\mathrm{X} 10^{9} / \mathrm{L}\right)\end{array}$ & $\begin{array}{l}4.12 \pm 1.51 \\
(0.40-20.0)\end{array}$ & $\begin{array}{l}7.64 \pm 1.91 \\
(4.0-11.3)\end{array}$ & $p=0.001 * *$ \\
\hline IV- P. Blast (\%) & $\begin{array}{l}11.58 \pm 6.75 \\
(1.0-68.0)\end{array}$ & - & - \\
\hline
\end{tabular}

Table (3): Blast cells count in bone marrow before and after induction in study group.

\begin{tabular}{llll}
\hline Item & \multicolumn{1}{c}{$\begin{array}{c}\text { Before } \\
\text { "n=30" }\end{array}$} & $\begin{array}{c}\text { After } \\
\text { "n=20" }\end{array}$ & $\begin{array}{c}p- \\
\text { value* }\end{array}$ \\
\hline $\begin{array}{l}\text { Blasts (\%): } \\
\text { Mean } \pm \text { SD }\end{array}$ & $\begin{array}{l}58.10 \pm 23.10 \\
(20.0-93.0)\end{array}$ & $\begin{array}{l}24.69 \pm 10.87 \\
(1.0-78.0)\end{array}$ & $p=0.000^{* * *}$ \\
Range & $\left(\begin{array}{l} \\
\hline\end{array}\right.$
\end{tabular}

Table (4): Differences in IL-6 and IL-10 serum levels in newly diagnosed patients and control groups.

\begin{tabular}{llll}
\hline Item & $\begin{array}{c}\text { Newly diagnosed } \\
\text { "n=30" } \\
\text { Mean } \pm \text { SD } \\
\text { Median (range) }\end{array}$ & $\begin{array}{c}\text { Control groups } \\
\text { "n=20" } \\
\text { Mean } \pm \text { SD } \\
\text { Median (range) }\end{array}$ & $\begin{array}{c}p \text { - } \\
\text { value* }\end{array}$ \\
\hline 1- IL-6 & $42.46 \pm 28.10$ & $1.53 \pm 1.42$ & $p=$ \\
$(\mathrm{pg} / \mathrm{ml})$ & $33.0(21.3-140.6)$ & $1.3(0.0-4.5)$ & $0.000^{*}$ \\
2- IL-10 & $177.68 \pm 103.46$ & $19.24 \pm 15.41$ & $p=$ \\
$(\mathrm{pg} / \mathrm{ml})$ & $162.8(26.0-432.0)$ & $13.1(4.1-58.2)$ & $0.000^{*}$ \\
\hline
\end{tabular}

Table (5): Differences in IL-6 and IL-10 serum levels in patients after induction and control groups.

\begin{tabular}{llll}
\hline Item & $\begin{array}{c}\text { After induction } \\
\text { "n=30" } \\
\text { Mean } \pm \text { SD } \\
\text { Median (range) }\end{array}$ & $\begin{array}{c}\text { Control groups } \\
\text { "n=20" } \\
\text { Mean } \pm \text { SD } \\
\text { Median (range) }\end{array}$ & $\begin{array}{c}p \text { - } \\
\text { value* }\end{array}$ \\
\hline 1- IL-6 & $37.02 \pm 26.36$ & $1.53 \pm 1.42$ & $p=$ \\
$(\mathrm{pg} / \mathrm{ml})$ & $29.1(10.7-125.3)$ & $1.3(0.0-4.5)$ & $0.000^{*}$ \\
$2-$ IL-10 & $135.60 \pm 87.62$ & $19.24 \pm 15.41$ & $p=$ \\
$(\mathrm{pg} / \mathrm{ml})$ & $130.5(16.0-270.5)$ & $13.1(4.1-58.2)$ & $0.000^{*}$ \\
\hline
\end{tabular}

Table (6): Differences in IL-6, IL-10 and TGF- $\beta$ serum levels in newly diagnosed patients (before induction) \& after induction.

\begin{tabular}{clll}
\hline Item & $\begin{array}{c}\text { Before induction } \\
\text { "n=30" } \\
\text { Mean } \pm \text { SD } \\
\text { Median (range) }\end{array}$ & $\begin{array}{c}\text { After induction } \\
\text { "n=30" } \\
\text { Mean } \pm \text { SD } \\
\text { Median (range) }\end{array}$ & $\begin{array}{c}p \text { - } \\
\text { value* }\end{array}$ \\
\hline 1- IL-6 & $42.46 \pm 28.10$ & $37.02 \pm 26.36$ & $p=$ \\
$(\mathrm{pg} / \mathrm{ml})$ & $33.0(21.3-140.6)$ & $29.1(10.7-125.3)$ & $0.000^{*}$ \\
2- IL-10 & $177.68 \pm 103.46$ & $135.60 \pm 87.62$ & $p=$ \\
$(\mathrm{pg} / \mathrm{ml})$ & $162.8(26.0-432.0)$ & $130.5(16.0-270.5)$ & $0.006^{*}$ \\
\hline
\end{tabular}

Table (7): Correlations between serum levels of IL-6 and IL10 concentrations and some of the laboratory parameters after induction chemotherapy.

\begin{tabular}{llllr}
\hline & \multicolumn{2}{c}{ IL-6 } & \multicolumn{2}{c}{ IL-10 } \\
\cline { 2 - 5 } & $r$-value & $p$-value & $r$-value & $p$-value \\
\hline Age & 0.090 & 0.635 & -0.012 & 0.948 \\
HB & -0.125 & 0.511 & -0.112 & 0.557 \\
WBCs & -0.057 & 0.766 & -0.259 & 0.167 \\
PLT & -0.299 & 0.108 & -0.211 & 0.263 \\
P. Blast & 0.265 & 0.157 & -0.036 & 0.850 \\
BM. Blast & 0.745 & $0.000 *$ & 0.304 & 0.103 \\
\hline
\end{tabular}

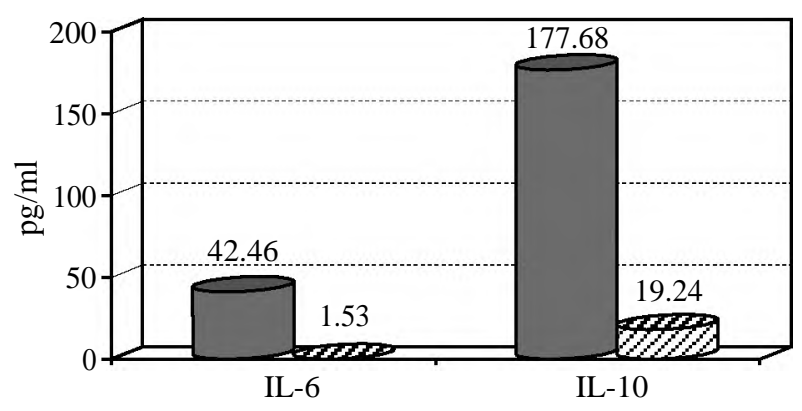

Study $\quad 2$ Control

Fig. (1): Differences in IL-6 \& IL-10 mean values of serum levels in newly diagnosed patients and control groups.

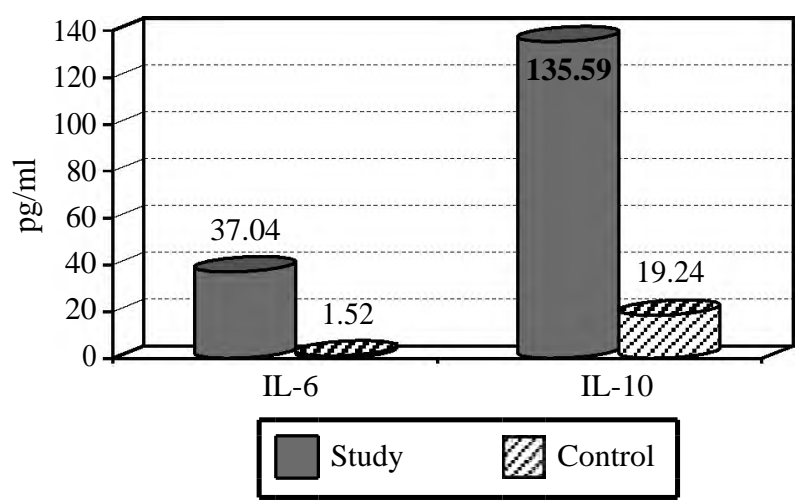

Fig (2): Differences in IL-6 \& IL-10 mean values of serum levels in patients after induction and control groups.

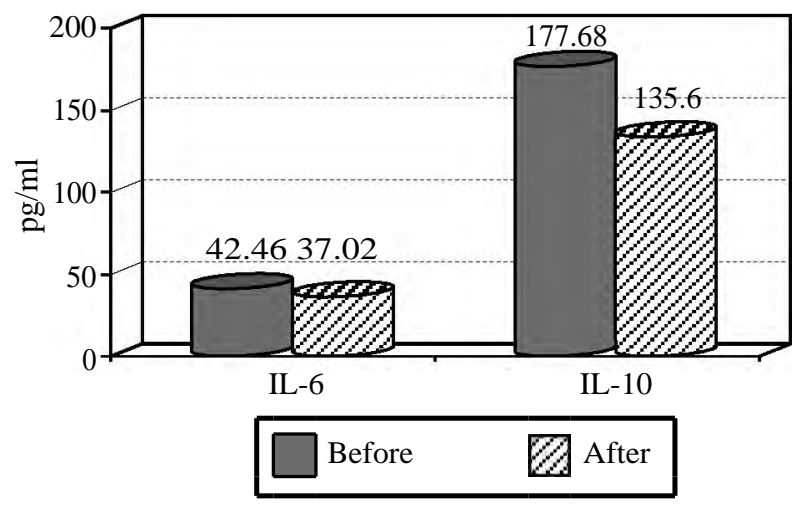

Fig. (3): Differences in IL-6 \& IL-10 mean values of serum levels in patients before induction \& after induction. 


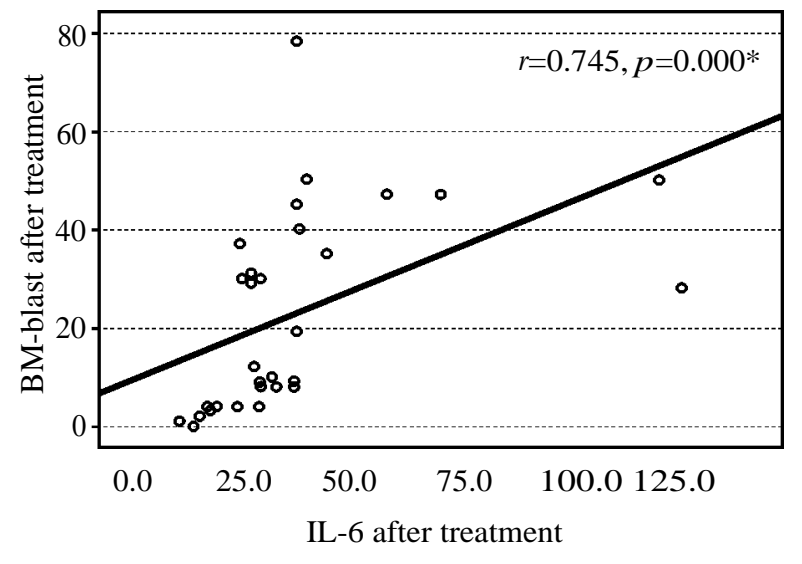

Fig. (4): Correlation between IL-6 and BM blast after induction chemotherapy.

\section{Discussion}

Acute Myeloid Leukemia (AML) is a lifethreatening hematopoietic stem cell neoplasm characterized by an increase in the number of myeloid cells in the bone marrow and an arrest in their maturation, frequently resulting in fatal infection, bleeding or organ infiltration, with or without leukocytosis $[\mathbf{1 , 1 5}$.

The etiology of AML is heterogeneous and complex, but it is widely accepted that both environmental and genetic factors play significant roles in the development of the disease. Immune system disorders have increased our understanding of leukemogenesis. However, little is known about the pathogenic events leading to the initiation and progression of this disease [2].

Cytokines are soluble molecules secreted by different types of cells in response to a variety of stimuli such as tissue damage or infection. In AML patients, cytokines can be produced by both leukemic blasts and cells of the immune system and the role of cytokines in the pathogenesis of acute leukemia has not been fully clarified $[7,16]$.

Thus, aberrant cytokine signaling is a feature of leukemia that may contribute to proliferation, blast survival, resistance to chemotherapy and patients' prognosis $[\mathbf{8 , 1 6}$. They regulate the immune response and other biologic processes, acting through a surface receptor, they provide target cells with specific information about conditions inside the organism, and cause a specific response. Under abnormal conditions, this physiological role of cytokines is maladaptive. The influence of inflammation and altered cytokine signaling on oncogenesis, leading to tumour progression, has been documented [17].
Interleukin-6 is produced mainly by monocytes and macrophages and in a smaller percentage by fibroblasts, endothelial cells, lymphocytes $\mathrm{T}$ and $\mathrm{B}$, chondrocytes and amnion cells. The production of interleukin- 6 is stimulated by interleukin-1 (IL1) and interferon (INF), Tumor Necrosis Factor (TNF), lipopolysaccharide, DNA viruses and RNA viruses [18] .

Interleukin-6 is a multifunctional cytokine with pleiotropic effects. Its importance lies in the stimulation of lymphocytes B differentiation and induction of permanent differentiation of lymphocytes $\mathrm{B}$ into plasma cells which produce different classes of immunoglobulin. Interleukin-6 stimulates lymphocytes $\mathrm{T}$ to the production of interleukin-2 (IL2) and the synthesis of its receptors. It can be constitutively expressed and markedly increased in AML cells [19].

The present study was carried out on the serum samples of 30 patients with AML and 20 controls which aimed to determine the role of two cytokines (IL-6 and IL-10) in the pathogenesis and outcome of AML before and after induction chemotherapy in the same patient group.

In this study, we found that the serum levels of IL 6 before the induction chemotherapy in the study group (newly diagnosed) were significantly higher than those after chemotherapy and the control group. Increased IL-6 levels decreased when patients responded to induction chemotherapy, suggesting that the measurement of IL- 6 concentrations may be valuable in the evaluation of therapeutic effect.

These results were in agreement with $\mathrm{Abd} \mathrm{El}$ Maksoud et al., who demonstrated that the serum concentrations of IL-6 in AML Newly Diagnosed (ND) and relapsed patients were significantly higher compared to control group and the concentration fall in remission [20].

Dawood also agreed with our results as they found that there was a significant increase in the serum level of IL- 6 concentration in the ND and relapsed patient group, while in remission group, serum IL-6 fall within the normal range when compared with control group. And also, found that there was inverse correlation between serum level of IL-6 in ND and relapsed patients with AML and heamoglobin percent and positive correlation with total leukocyte count [21].

Sun agreed with our results however they used plasma from bone marrow samples as they found elevated level of IL-6 in bone marrow of AML- 
ND patients which is consistent with what $\mathrm{Wu}$ and Fredly et al., had reported [22-24].

Also, Tian et al., agreed with our study as they demonstrated markedly elevated concentration of IL-6 in ND AML patients but in their BM plasma samples [25].

On the other hand, Alizadeh et al., didn't confirm these results as they found that IL-6 serum level in the AML patient group was lower than control group [26].

Treg cells, a subpopulation of CD4 + T cells, inhibit the immune response by influencing the activity of other cell types. Typically, Treg cells are classified into naturally occurring CD4 + CD25 + Treg cells, IL-10 secreting Treg cells, and TGF0 secreting Treg cells based on the types of cytokines they produce [27].

Previously, elevated levels of regulatory $\mathrm{T}$ (Treg) cells in a variety of hematological malignancies including AML have been reported $[3,4]$ Patients with a lower Treg cell frequency at diagnosis have a better response to induction chemotherapy and a favorable prognosis $[4,28]$

Interleukin-10 is known to inhibit cytokine production by $\mathrm{T}$ cells, and exerts anti-inflammatory and immunosuppressive activities. It inhibits the production of IL-2, IFN gamma and granulocyte macrophage colony stimulating factors as well as the proliferative response to Thelper 1 cells [29]

As regard our results concerning IL-10 we found that the serum level of IL-10 before the chemotherapy in the study group (newly diagnosed patients) were significantly higher than those after chemotherapy and control group. Increased IL-10 levels decreased when patients respond to induction chemotherapy.

These results were in accordance with Sun et al., as they found that the peripheral serum level of IL-10 in AML ND patients was much higher than that in complete remission patients or controls and similar elevated level of IL-10 in bone marrow plasma of AML-ND patients [24]

Wu et al., agreed with our study and demonstrated that AML ND patients also had increased plasma IL-10 levels compared with complete remission patients and control group [30]

Musuraca et al observed a significantly higher increase in the frequency of IL-10 + secreting cells in AML ND patients than the healthy controls [31]
Yao et al., [34] agreed with our study but they used gene expressing IL-10 mRNA from the BM samples of the AML patients. They revealed that the IL-10 expression in the newly diagnosed AML patients was higher than the non-tumor controls, this indicated the leukemic cells in bone marrow could secret IL-10 in an autocrine way as the local secretion of IL-10 in the tumor growth process, may cause the loss of the sensitivity to cytotoxic $\mathrm{T}$ lymphocytes and make the growth of tumor cells easier. This result was similar to the published paper [32], IL-10 mRNA of remission group (by chemotherapy) was significantly decreased when compared with the newly diagnosed AML group, but still higher than the non-tumor controls. They concluded that this may be due to the chemotherapy which inhibits the growth and activity of the leukemic cells and affects the function of the patients' immune system $[33,34]$.

\section{Conclusion:}

We have demonstrated that AML patients before induction chemotherapy had increased serum concentrations of IL- 6 and IL-10 and their levels start to decrease after the induction. These results open a new avenue in the study of tumor immunotherapy.

Conflicts of interest: There are no conflicts of interest.

\section{References}

1- FRITSCHE-POLANZ R., FRITZ M., HUBER A., et al.: High frequency of concomitant mastocytosis in patients with acute myeloid leukemia exhibiting the transforming KIT mutation D816V. Mol. Oncol., 4: 335-46, 2010.

2- BARRETT A.J. and Le BLANC K.: Immunotherapy prospects for acute myeloid leukaemia. Clin. Exp. Immunol., 161: 223-32, 2010.

3- WANG X., ZHENG J., LIU J., YAO J., HE Y., LI X., YU J., YANG J., LIU Z. and HUANG S.: Increased population of CD4(+) CD25(high), regulatory T cells with their higher apoptotic and proliferating status in peripheral blood of acute myeloid leukemia patients. Eur. J. Haematol., 75: 468-76, 2005.

4- SHENGHUI Z., YIXIANG H., JIANBO W., et al.: Elevated frequencies of CD4(+) CD25(+) CD127(lo) regulatory T cells is associated to poor prognosis in patients with acute myeloid leukemia. Int. J. Cancer, 129: 1373-81, 2011.

5- DOHNER H., ESTEY E.H., AMADORI S., APPELBAUM F.R., BUCHNER T., BURNETT A.K., et al.: Diagnosis and management of acute myeloid leukemia in adults: recommendations from an international expert panel, on behalf of the European Leukemia Net. Blood, 115: 453$74,2010$.

6- ESTEY E.H.: Acute myeloid leukemia: Update on diagnosis, risk stratification, and management. Am. J. Hematol., 87: 89-99, 2012. 
7- PANJU A.H., DANESH A., MINDEN M.D., KELVIN D.J. and ALIBHAI S.M.: Associations between quality of life, fatigue, and cytokine levels in patients aged 50+ with acute myeloid leukemia. Support Care Cancer, 17: 539-46, 2009

8- TSIMBERIDOU A.M., ESTEY E., WEN S., PIERCE S., KANTARJIAN H., ALBITAR M. and KURZROCK R.: The prognostic significance of cytokine levels in newly diagnosed acute myeloid leukemia and high-risk myelodysplastic syndromes. Cancer, 113 (7): 1605-13, 2008.

9- STEENSBERG A., FISCHER C.P., KELLER C., MOLLER K. and PEDERSEN B.K.: IL-6 enhances plasma IL1ra, IL-10, and cortisol in humans. Am. J. Physiol. Endocrinol. Metab., 285: E433-7, 2003.

10- WIERENGA A.T.J., SCHURINGA J.J., EGGEN B.J.L., KRUIJER W. and VELLENGA E.: Downregulation of IL-6-induced STAT3 tyrosine phosphorylation by TGFsz1 is mediated by caspase-dependent and -independent processes. Leukemia, 16 (4): 675-82, 2002.

11-BENDALL L.: Chemokines and their receptors in disease. Histol. Histopathol., 20 (3): 907-26, 2005.

12-WU S., GESSNER R., TAUBE T., VON STACKELBERG A., HENZE G. and SEEGER K.: Expression of interleukin10 splicing variants is a positive prognostic feature in relapsed childhood acute lymphoblastic leukemia. J. Clin. Oncol., 23: 3038-42, 2005.

13- KIMURA A., KISHIMOTO T.: IL-6: Regulator of Treg/ Th17 balance. Eur. J. Immunol., 40: 1830-5, 2010.

14- STENVINKEL P., KETTELER M., JOHNSON R.J., LINDHOLM B., PECOITS-FILHO R., RIELLA M., et al.: IL-10, IL-6, and TNF-alpha: Central factors in the altered cytokine network of uremia-the good, the bad, and the ugly. Kidney Int., 67: 1216-33, 2005.

15- LOWENBERG B., DOWNING J.R. and BURNETT A.: Acute myeloid leukemia. N. Engl. J. Med., 341: 105162, 1999.

16- PANTELI K.E., HATZIMICHAEL E.C., BOURANTA P.K., KATSARAKI A., SEFERIADIS K., STEBBING J., et al.: Serum interleukin (IL)-1, IL-2, sIL-2Ra, IL-6 and thrombopoietin levels in patients with chronic myeloproliferative diseases. Brit. J. Haematol., 130: 709-15, 2005.

17- COUSSENS L.M. and WERB Z.: Inflammation and cancer. Nature, 420 (6917): 860-7, 2002.

18- GOL AB J., JAKÓBISIAK M., LASEK W., et al.: Cytokiny. Immunologia. Warszawa, Wyd Nauk PWN, 15: 198-205, 2002.

19- HSU H.C., LEE Y.M., TSAI W.H., JIANG M.L., HO C.H., HO C.K. and WANG S.Y.: Circulating levels of thrombopoietic and inflammatory cytokines in patients with acute myeloblastic leukemia and myelodysplastic syndrome. Oncology, 63 (1): 64-9, 2002.

20- ABD EL-MAKSOUD N., RAGAB M.H., ABD EL-LATIF M.M. and ABDALLA S.H.: Prognostic Impact of Elevated Serum Hyulronic Acid, Ferritin and Interleukin-6 in Patients with Acute Myeloid Leukemia. Journal of American Science, 532-41. ISSN: 1545-1003, 2002.
21- DAWOOD D.S.: Assessment of IL-6 Serum Level in Patients With Acute Myeloid Leukemia. Iraqi Journal of Cancer and Medical Genetics, Vol. 4, No. 1, PP. 22-8. ijcmg@iccmgr.com, 2011.

22- WU C., WANG S., WANG F., CHEN Q., PENG S., ZHANG Y., QIAN J., JIN J. and XU H.: Increased frequencies of $\mathrm{T}$ helper type 17 cells in the peripheral blood of patients with acute myeloid leukaemia. British Society for Immunology, Clinical and Experimental Immunology, 158: 199-204, 2009.

23- FREDLY H., REIKVAM H., GJERTSEN B.T. and BRUSERUD O.: Disease-stabilizing treatment with alltrans retinoic acid and valproic acid in acute myeloid leukemia: Serum hsp70 and hsp90 levels and serum cytokine profiles are determined by the disease, patient age, and anti-leukemic treatment. Am. J. Hematol., 87: 368,2012

24- SUN Y.X., KONG H.L., LIU CH.F., YU S.H., TIAN T., MAA D.X. and JI CH.Y.: The imbalanced profile and clinical significance of $\mathrm{T}$ helper associated cytokines in bone marrow microenvironment of the patients with acute myeloid leukemia, Human Immunology, 75: 113-8, 2014.

25- TIAN T., YU S.H., WANG M., YUAN C., ZHANG H., JI C.H. and MA D.: Aberrant T Helper 17 Cells and Related Cytokines in Bone Marrow Microenvironment of Patients with Acute Myeloid Leukemia. Hindawi Publishing Corporation, Clinical and Developmental Immunology, Vol. 2013, Article ID 915873, 10 pages. http://dx.doi.org/ 10.1155/2013/915873, 2013.

26- ALIZADEH S.H., BOHLOLI S.H., ABEDI A., MOUSAVI S.H., DARGAHI H., JAFARZADEH B., HAMRANG N. and IMANI A.: Investigation of Leptin, Leukemia Inhibitory Factor (LIF), and IL-6 Serum Levels in Myeloid Leukemia. Iranian Journal of Blood and Cancer, Vol. 2, No. 4, IJBC 3: 95-100, 2011.

27- SAKAGUCHI S.: Regulatory T cells: History and perspective. Methods Mol. Biol., 707: 3-17, 2011.

28- SZCZEPANSKI M.J., SZAJNIK M., CZYSTOWSKA M., MANDAPATHIL M., STRAUSS L., WELSH A., FOON K.A., WHITESIDE T.L. and BOYIADZIS M. Increased frequency and suppression by regulatory $\mathrm{T}$ cells in patients with acute myelogenous leukemia. Clin. Cancer Res., 15: 3325-32, 2009.

29- MOCELLIN S., WANG E. and MARINCOLA F.M.: Cytokines and Immune Response in the Tumor Microenvironment. Journal of Immunotherapy: Review, Vol. 24Issue 5-pp. 392-407, 2001.

30- WU H.A.O., PENG L.I., SHAO A., JINGJING M.A., MIN J.I., et al.: Aberrant expression of Treg associated cytokine IL-35 along with IL-10 and TGF-beta in acute myeloid leukemia, 1119-23, 2012.

31- MUSURACA G., MATTEIS S., NAPOLITANO R., PAPAYANNIDIS C., GUADAGNUOLO V., FABBRI F., CANGINI D., CECCOLINI M., GIANNINI M.B., LUCCHESI A., RONCONI S., MARIOTTI P., SAVINI P., TANI M., FATTORI P.P., GUIDOBONI M., MARTINELLI G., ZOLI W., AMADORI D. and CARLONI S.: IL-17/IL-10 double-producing T cells: New link between infections, immunosuppression and acute myeloid 
leukemia. J. Transl. Med., 13: 229 Doi 10.1186/s12967015-0590-1, 2015.

32- YANG Y., ZHANG W.G., QIAO Y.C., et al.: The quantitate method of serum IFN-y and IL-10 in AML patients. Chin. J. Hematol., 23: 371-2, 2002.

33- HSIEH C.L., CHEN D.S. and HWANg L.H.: Tumorinduced immunosuppression: A barrier to immunotherapy of large tumors by cytokine-secreting tumor vaccine. Hum. Gene Ther., 11: 681-92, 2000.

34- YAO CH.J., DU W., CHEN H.B., XIAO S.H., WANG CH.H. and FAN ZI LI: Associations of IL-10 Gene Polymorphisms with Acute Myeloid Leukemia in Hunan, China. Asian Pacific Journal Cancer Prev., Vol. 14 (4): 2439-42, 2013.

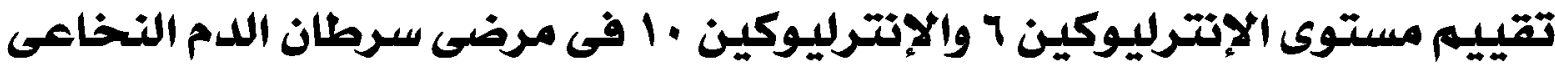

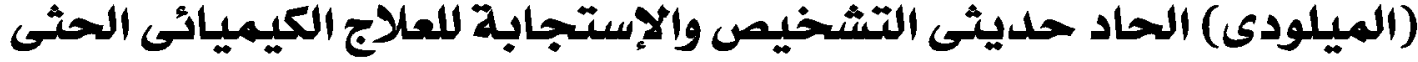

سرطان الدم الحاد هو الآودام الخبيثة الدموية الآكثر شيوعا لدى البالغين، والتى تتميز بالإنتشار المشوه للخلايا المستمدة من نخاع العظام

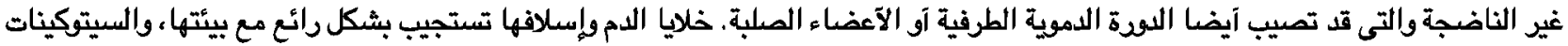

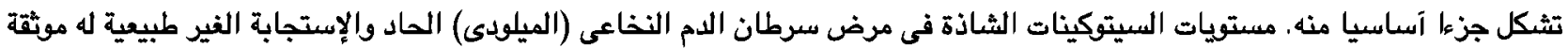

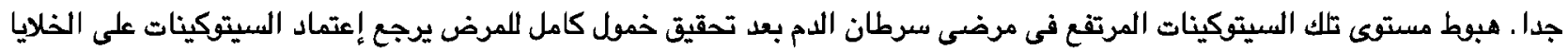
الجزعية الآولية المفرزة آثاء نشاط المرض. فى هذه الدراسة قمنا بإستخدام مجموعة (الايلايزا)، لتقدير مستويات الإنترليوكين-7 والإنترليوكين-

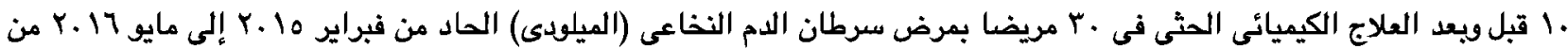

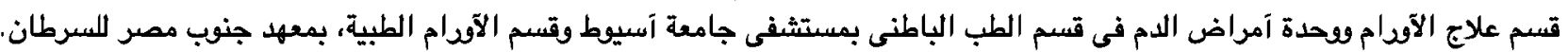

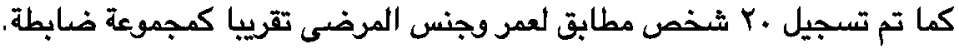

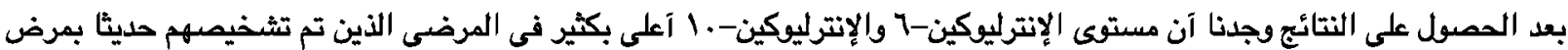

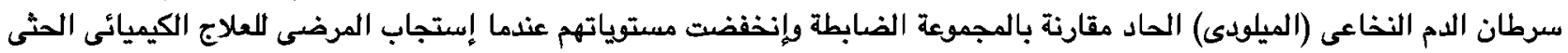

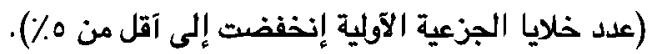

الخلاصدة:ظهرت دراستنا إنخفاضا فى مستوى الإنترليوكين-7 والإنترليوكين- إنى مرضى سرطان الدم النخاعى (الميلودى) الحاد بعد العلاج الكيميائى الحثى، مما يشير إلى آن تقييم مستويات تلك الإنترليوكينات يمكن آن تستخدم كعلامات تتذيرية ومفيدة في تقييم تآثير

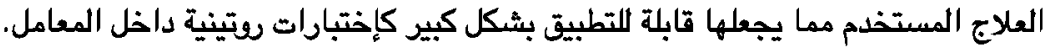

